\title{
Acetyl-Tethering Silica as a Novel Reagent for Acetylation of Alcohols under Mild and Heterogeneous Conditions
}

\author{
Farhad Shirini," Mohammad Ali Zolfigol, and K. Mohammadi \\ Depatment of ('hemistm, ('ollege of Science, ( \\ 'Department of (hemisty, College of Science, But-Ali, Sina Linversit, P.O. Box 4135, Hamadan 65/74, IR. Iran \\ Received December 20,2002
}

Key Words : Acety l-lethering silica, Acetylation, Alcohols

During the multistep synthesis of natural products. the efficiency of the synthetic protocol employed often dependes largely on protection and deprotection of functional groups involved. To this end. protecting groups have been playing a curcial role during the synthesis of complex natural products.' Among the various protecting groups used for hydroxyl function. acetyl is the most common group in riew of its easy introduction.stability to acidic reaction conditions and also ease in its removal by mild alkaline hydrolysis. Acetylation is normally performed by using acetic anhydride or acetyl chloride in the presence of a base such as triethylamine or pyridine. Further. the rate of acetylation is known to be increased mainfoldly if 4dimelhylaminopyridinc is used as a co-catalyst. ${ }^{2} p$ Tolucnesulfonic acid (a protic acid) and Lewis acids such as $\mathrm{TiCl}_{4} / \mathrm{AgClO}_{+}{ }^{+} \mathrm{CoCl}_{2}{ }^{5} \mathrm{Cu}(\mathrm{OTO})_{2} .{ }^{6} \mathrm{Sc}(\mathrm{OTO})_{3}{ }^{7} \mathrm{TaCl}_{5 .}{ }^{.}$ $\mathrm{MgBr}_{2}$ ? $\mathrm{FeCl}_{3}{ }^{10} \mathrm{Cu}\left(\mathrm{NO}_{3}\right)_{2}, 3 \mathrm{H}_{2} \mathrm{O}^{13}$ have bece used to acety late alcohols. Apart from these cataly sts. TMSOT! ${ }^{12}$ and $\mathrm{TMSCl}^{13}$ have been used as efficient catalysts for acetylation of alcohols. There have been efforts to introducc solid reagents for casicr work-ups. In this regard montmorillonite K-10.14.15 $\mathrm{KSF}^{15}$ Zcolitc HSZ-360). ${ }^{16}$ and $\mathrm{KF}-\mathrm{Al}_{2} \mathrm{O}_{3}{ }^{17}$ have been used.

In continuation of our studies on the applications of chloride-tcthering. ${ }^{18.19}$ we found that chloride-lethering silica ${ }^{21}$ in reaction with glacial acetic acid can be converted

$$
\mathrm{SiO}_{2}-\mathrm{Cl}+\mathrm{CH}_{3} \mathrm{CO}_{2} \mathrm{H} \longrightarrow \mathrm{SiO}_{2}-\mathrm{OAC}+\mathrm{HCl} \uparrow
$$

(1)

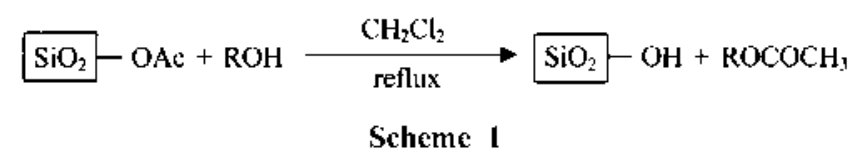

easily to the acetyl-tethering silica (I). It is interesting to note that the reaction is easy and clean, not requiring any complex work-up procedure because the evolved $\mathrm{HCl}$ gas can be removed from the reaction vessel immediately. We belived that acetyl-tethering silica would be an superior acyl source. therelore we were interested in using this resin for accly lation of alcohols (Scheme I). All reactions were performed under mild and heterogencous conditions in refluxing dichloromethane. The results are tabulated in Table. Formation of the mixture of the products. causes that this methodology can not be used for the acctylation of ally lic alcohols (Table I. Entry I I).

In conclusion, acctyl-tchering silica is a good acyl source in terms of convenicnce. cheapness. casy production and insolubility in organic solvents. Practical and efficicnt acclylation of alcohols werc achicsed by the present methodology: The chcapness and availability of the reagents. easy procedure and work-up make this method attractive

Table 1. Acetylation of alcohols with acety l-tethetring silica in refluxing dichloromethane

\begin{tabular}{|c|c|c|c|c|}
\hline Entry & Substate & Time (hr) & Product & Yicld ${ }_{0}{ }^{a t h}$ \\
\hline 1 & 4-ClC. $\mathrm{H}_{1} \mathrm{CH}_{2} \mathrm{OH}$ & 1 & $4-\mathrm{Cl}_{6} \mathrm{H}_{1} \mathrm{CH}_{2} \mathrm{OAC}$ & 90 \\
\hline 2 & $2-\mathrm{ClC}_{\mathrm{N}} \mathrm{H}_{1} \mathrm{CH}_{2} \mathrm{OH}$ & 1.5 & $2-\mathrm{ClC}_{6} \mathrm{H}_{1} \mathrm{CH}_{2} \mathrm{OAc}$ & 93 \\
\hline 3 & $4-\mathrm{BrC}_{n} \mathrm{H}_{1} \mathrm{CH}_{2} \mathrm{OH}$ & 1 & $4-\mathrm{BrC}_{n} \mathrm{H}_{1} \mathrm{CH}_{2} \mathrm{OAC}$ & 92 \\
\hline 4 & $2-\mathrm{BrC}_{n} \mathrm{H}_{3} \mathrm{Cl}_{2} \mathrm{OH}$ & 1 & $2-\mathrm{BrC}_{n} \mathrm{H}_{1} \mathrm{CH}_{2} \mathrm{OAc}$ & 95 \\
\hline 5 & $2-\mathrm{NO}_{2} \mathrm{C}_{n} \mathrm{H}_{1} \mathrm{C}_{2} \mathrm{OH}$ & 2 & $2-\mathrm{NO}_{2} \mathrm{C}_{6} \mathrm{H}_{1} \mathrm{CH}_{2} \mathrm{OAc}$ & 85 \\
\hline 6 & $2-\mathrm{CH}_{3} \mathrm{C}_{\mathrm{r}} \mathrm{H}_{1} \mathrm{CH}_{2} \mathrm{OH}$ & 1 & $2-\mathrm{CH} \mathrm{C}_{n} \mathrm{H}_{1} \mathrm{CH}_{2} \mathrm{OAC}$ & 90 \\
\hline 7 & $\mathrm{C} \cdot \mathrm{H}: \mathrm{CH}(\mathrm{OH}) \mathrm{CH}$ & 1.5 & $\mathrm{C}_{n} \mathrm{H}_{i} \mathrm{CH}(\mathrm{OAc}) \mathrm{CH}$ & 87 \\
\hline 8 & $\mathrm{C}_{3} \mathrm{H}_{2} \mathrm{CH}_{2} \mathrm{CH}_{2} \mathrm{CH}_{2} \mathrm{OH}$ & 1.5 & $\mathrm{C}_{6} \mathrm{H}_{4} \mathrm{CH}_{2} \mathrm{CH}_{2} \mathrm{CH}_{2} \mathrm{OAc}$ & 85 \\
\hline 9 & $\mathrm{C}_{6} \mathrm{H}_{2} \mathrm{C}_{2} \mathrm{CH}(\mathrm{OH}) \mathrm{CH}_{2}$ & 1.5 & $\mathrm{C}_{6} \mathrm{H}_{3} \mathrm{CH}_{2} \mathrm{CH}(\mathrm{OAc}) \mathrm{CH}:$ & 90 \\
\hline 10 & Cyclohexyl-OH & 1.5 & Cyclohexyl-OAc & 80 \\
\hline 11 & $\mathrm{C}_{\mathrm{N}} \mathrm{H}: \mathrm{CH}-\mathrm{CHCH}_{2} \mathrm{OH}$ & 3 & $\mathrm{C}_{6} \mathrm{H}_{4} \mathrm{CH}^{-} \mathrm{CHCH}_{2} \mathrm{OAC}$ & $-c$ \\
\hline
\end{tabular}

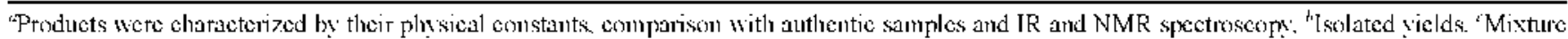
of products.

\footnotetext{
* lo whom correspondence should be addressed. E-mail: shiriniợguilan.ac.ir
} 
for the large-scale operations. The other importance of this methodology is the regeneration of silica gel which can be used for the preparation of chloride-tethering silica and acety l-1ethering silica for several times. Morcover. a new feature here is the fact that the reaction is heterogencous. This could be worthwile in an industrial setting."

\section{Experimental Section}

Preparation of acetyl-tethering silica: To chloridetethering silica $(2 \mathrm{~g})$ in $50 \mathrm{~mL}$ suction flask which was equipped with a gas inlet tube for conducting $\mathrm{HCl}$ gas over an adsorbing solution i.e. water and a drying tube was added glacial acetic acid $(10 \mathrm{~mL})$ and shaken for $1 \mathrm{hr}$. The mixture was filtered and the white solid residue was washed with acetone $(5 \mathrm{~mL})$, and stored in a tightly capped bottle. [IR (KBr): $1620,1200.1060 \mathrm{~cm}^{-1}$ ].

General procedure: A mixture of the substrate (1 $\mathrm{mmol})$ and acety-tethering silica $(0.6 \mathrm{~g})$ in dry dichloromethane $(5 \mathrm{~mL})$ was heated at reflux for the specified time (Table 1). The reaction was monitored by TLC. After completion of the reaction. the mixture was filtered and the filtrate was washed with dichloromethane (10 $\mathrm{mL}$ ). Evaporation of the solvent gave the corresponding esters in good to high yiclds.

Acknow ledgement. We appreciate the financial support of this work by the Guilan University Research Council.

\section{References}

1. Greene, T. W: Wuts, P. G. Protective Gronps in Ongemic
Synthesis. $3^{\text {rul }}$ ed.: John Wiley \& Sons: New York. 1991 .

2. (a) Holle. G.: Sleglich. V: Vorbrugen. H. ingen. (hem. Int F.d Fongl 1978. 17. 569. (b) Seriven. E. f., V. (hem. Soc. Rew 1983. 12. 129

3. Cope, A. C.: Herrick, Г. C. Org. Sinth. 1963. Coll rot $4,304$.

4. Miyashita, M.; Shiina. I.: Miyoshi. S.: Mukaiyana. T. Bull. Chum. Soc. Jpn. 1993. 66. 1516.

5. Iqubal. ..: Srivastava. R. R.J. Org. (hem. 1992. 57. 2001.

6. Saratanan. P'.: Singh. V. K. Tetrohedron Lett. 1999. f0. 2611.

7. 7.hao, HI: Pendri. A.: Greenuald, R. B. J. Org. Chkm. 1948. 63, 7559

8. Chandrasekahar. S.: Ramachander. T.: Takhi. M. Tetrdhedirm Letl. 1998.39 .6081

9. Vedejs. E.: Dauguls. O.J. Ory. Chem. 1996. 61.5702.

10. Sharma. G. V. M.: Mahalingam. A. K.: Nagarajan. M.: Ilangonan. A.: Radhaktishtna. P. Sintett 1999. 1200.

11. Iranpoor. N.: Firouzabadi, H.: 7.oltigol. M. A. Sinth. Commm. 1998, 28. 1923.

12. I'rocopion. P'. A.: Bangh. S. I? D.: Flack. S. S.: Inglis. G. G. A. Chem Common, 1996. 2625.

13. Kumareswaran. R.: Gupta. A.: Vankar. Y. D. Sinth. C'ommmh. 1997, 27. 277

14. I.i, A.X.: I.i, T.-S.: Ding. T.-I. Chem. Commm 1997. 1389.

15. Bhaskar. P. M.: Ioganathat. D. Fefrohedron Lett. 1998. 39. 2215.

16. Ballini. R.: Bosica. G.: Carloni. S.: Ciaralli. L.: Maggi. R.: Sartori. G. Tetrohedron Lett, 1998. 39.6049.

17. Yadav. V. K.: Babu. K. G.: Millal. M. Fetrahedron 2001. 57. 7047

18. 7oltigol. M. A.: Shirini, F.: Ghorbani Chogamarani, A. Symh. Comman. 2002. 32. 1809 .

19. Zollicol. M. A.: Torabi. M.: Mallakpour. S. E. Tetratedron 2001. 57.8381 .

20. For preparation of silica chloride see : Firouzabadi. H.: Irampoor. N.: Karimi. B.: I Iazaarkhani, H. Simkrr 2000, 263.

21. Reigo, I. M.: Scdin, 7.: 7.aldivar, J. M.: Marziano, N. C.: Tortato. C. Ithahedron Letl. 1996, 37, 51.3. 